Dr BOJAN SIMIĆ, naučni saradnik

Institut za noviju istoriju Srbije

Beograd, Trg Nikole Pašića 11

bojan.simic@inis.bg.ac.rs

UDK 94:327(450:497.11)"1937"(093.2)

originalan naučni rad

32:929 Стојадиновић М.(093.2)

primljeno: 31. jul 2016.

prihvaćeno: 8. februar 2017.

\title{
POSETA MILANA STOJADINOVIĆA ITALIJI DECEMBRA 1937.*
}

APSTRAKT: U radu se na osnovu italijanskih i domaćih izvora $i$ štampe analizira poseta predsednika vlade i ministra spoljnih poslova Kraljevine Jugoslavije Milana Stojadinovića Italiji, u decembru 1937. godine. Razmatra se ono što je prethodilo poseti, njen tok, značaj i recepcija u najznačajnijim listovima obe države.

KLJUČNE REČI: Italija, Jugoslavija, Milan Stojadinović, spoljna politika, diplomatija, štampa, propaganda

U Evropi koja je krajem tridesetih godina 20. veka nezadrživo klizila u novi svetski rat vođenje spoljne politike jedne relativno male države bio je delikatan i zahtevan posao. U Kraljevini Jugoslaviji tu odgovornu dužnost od juna 1935. do februara 1939. obavljao je Milan Stojadinović. Ta politika zasnivala se na bilateralnim sporazumima, postepenom udaljavanju od Francuske i približavanju Nemačkoj i Italiji, a sprovođena je uz saglasnost kneza Pavla i podršku Britanaca. ${ }^{1}$ Uzroke učinjenog zaokreta treba tražiti u slabljenju značaja Društva naroda, Francuske i sistema kolektivne bezbednosti s jedne i jačanju fašističkih država s druge strane. Politiku koju je Stojadinović vodio ocenjivao je kao „čuvanje starih prijateljstava i stvaranje novih“.2

Odnosi sa Italijom činili su jedno od ključnih mesta u spoljnoj politici koju je sprovodio Milan Stojadinović dok je bio predsednik vlade i ministar spoljnih poslova. U tim odnosima 1937. godina posebno je značajna. Početkom te godine započeli su pregovori o jugoslovensko-italijanskom sporazumu koji su parafirani 25. marta $\mathrm{u}$ Beogradu. ${ }^{3}$ Većina savremenika i istoričara slaže se da je ovim sporazumom Jugos-

\footnotetext{
* Rad je deo projekta Tradicija i transformacija - istorijsko nasleđe i nacionalni identitet $u$ Srbiji u 20. veku (47019), koji finansira Ministarstvo prosvete, nauke i tehnološkog razvoja Republike Srbije.

${ }^{1}$ Bogdan Krizman, Vanjska politika jugoslavenske države 1918-1941 (Zagreb: Školska knjiga, 1975), 8; Todor Stojkov, Vlada Milana Stojadinovića (Beograd: Institut za savremenu istoriju, 1983), 36; Dušan Biber, „O padu Stojadinoviće vlade“, Istorija 20. veka, Zbornik radova, VIII, (1966), 6.

${ }^{2}$ O najnovijem osvrtu na ovaj segment Stojadinovićeve politike videti: Миша Ђурковић, „Спољна политика Милана Стојадиновића“, у: Милан Стојадиновић: Политика у време глобалних ломова, Зборник радова, приредио Миша Ђурковић (Београд: Завод за уџбенике, 2013), 44-74.

${ }^{3} \mathrm{O}$ toku pregovora videti: Živko Avramovski, Balkanske zemlje i velike sile 1935-1937 (Beograd: Prosveta, 1968), 267-285; Massimo Bucarelli, Mussolini e la Jugoslavia 1922-1939 (Bari: Edizioni B. A. Graphis, 2006), 336-361.
} 
lavija dobila više, a to se odnosilo na: garantovanje međusobnih granica, odricanje Italije od podrške ustaškoj emigraciji i davanje određenih prava jugoslovenskoj nacionalnoj manjini. S druge strane, Jugoslavija je priznala dotadašnju italijansku poziciju u Albaniji. Značaj sporazuma za Italiju nije bio u samim odredbama već se na njega gledalo kao na zalog za budućnost. Musolini je želeo da sporazumom sa Jugoslavijom svog suseda odvoji od Francuske, Male i Balkanske antante, privuče Italiji, a u isto vreme smanji rastući nemački uticaj. ${ }^{4}$

\section{Priprema posete}

Krajem 1937. Milan Stojadinović je vodio živu diplomatsku aktivnost. U Parizu je potvrdio francusko-jugoslovenski pakt iz 1927. godine. U Londonu se sreo sa premijerom Čemberlenom i ministrom spoljnih poslova Idnom. Nakon toga je putovao u Italiju, a nedugo zatim posetio je i Hitlerovu Nemačku. Sve navedeno istoričar Jakob Hoptner opisuje kao „metodično kretanje kroz evropski diplomatski lavirint“. 5 . Možda i najbitnija stanica na tom putu bio je Rim.

Poseta Stojadinovića Italiji u decembru 1937. formalno je bila uzvratna poseta grofu Ćanu za onu koju je italijanski ministar napravio marta iste godine kada je potpisan Beogradski sporazum. Već tada ona je bila načelno dogovorena za kraj 1937, ali je ostalo da se datum uskladi sa obavezama dva ministra. Dogovor je išao preko italijanskog poslanstva u Beogradu i agilnog poslanika Indelija. ${ }^{6}$ Aktivnije se na tome radilo u septembru kada se Stojadinović spremao za posetu Francuskoj i Engleskoj. Kao mogući datumi pominjani su sredina ili kraj novembra. Stojadinović je ljubazno ponudio grofu Ćanu da on izabere. Ono što je mnogo važnije u samom dokumentu jeste što je Stojadinović preko Indelija uveravao Italiju da će pakt sa Francuskom biti produžen bez ikakvih izmena i dopuna, a da će Francuzima jasno staviti do znanja kako je za Jugoslaviju nemoguće da „posle sređivanja odnosa sa Italijom uđe u nejasne i nekorisne kombinacije, koje bi mogle biti protumačene kao da su u suprotnosti sa tim odnosima“".7 Navedeno se pre svega odnosilo na predloženi pakt o uzajamnoj pomoći država Male antante koji je protežirala Francuska. Iz dokumenta vidimo da je Stojadinović do detalja upoznao Indelija sa planovima za svoju posetu Parizu, kako će se postaviti i šta želi da postigne.

Preciziranje datuma posete usledilo je početkom novembra kada je Ćano u dopisu Indeliju predložio period između 6. i 10. decembra. U okviru boravka grof je

${ }^{4}$ Renzo de Felice, Mussolini il duce, Lo Stato totalitario 1936-1940 (Torino: Einaudi, 1981), 404; Ž. Avramovski, Balkanske zemlje i velike sile, 286-288; M. Bucarelli, n. d., 363-364. Živko Avramovski prenosi da je nemački ambasador Heren (Victor von Heeren) rekao da je „Jugoslavija strana koja dobija a Italija strana koja daje“. Britansko poslanstvo u Beogradu u godišnjem izveštaju zaključuje: „Jugoslovenska vlada je, barem na papiru, ostvarila značajne prednosti“. Živko Avramovski, Britanci o Kraljevini Jugoslaviji II (Zagreb: Globus, 1986), 559.

${ }^{5}$ Jacob B. Hoptner, Jugoslavija u krizi 1934-1941 (Rijeka: Otokar Keršovani, 1972), 116.

${ }^{6}$ Mario Indeli (Indelli), italijanski diplomata, rođen 1896. u Firenci. Pravni fakultet je završio u Bolonji. Pre dolaska u Beograd (7. avgust 1936) dve godine je bio poslanik u Albaniji. Nakon višegodišnjeg službovanja u jugoslovenskoj prestonici postavljen je za poslanika u Tokiju (1940).

${ }^{7}$ I Documenti Diplomatici Italiani (DDI), Ottava serie: 1935-1939, Volume VII, (1. jul - 31. decembar 1937) (Roma: Istituto Poligrafico e Zecca dello Stato, 1997), br. 378, 459. 
predvideo i posetu jednom industrijskom centru i vojnom kompleksu. Poručio je Indeliju da podrži Stojadinovića na putu koji je on do sada „verno sledio“, što je Ćano bio „srećan i zadovoljan da prizna“. ${ }^{8}$ Stojadinović je brzo pristao na predlog tako da je Indeli već 10. oktobra izvestio da je nakon razgovora sa jugoslovenskim predsednikom vlade sve utanačeno.

Deluje da su obe strane sa nestrpljenjem čekale posetu. O značaju posete i svog gosta Ćano beleži u svom dnevniku: „Pripreme za Stojadinovićevu posetu su završene. Stiže večeras u 21:50. Ići ću na železničku stanicu sa Dučeom. Pobrinuo sam se i za najsitnije detalje ove posete. Želim da se ovom čoveku, koji se pokazao iskren prijatelj, ukaže izuzetan doček. Na prvom mestu jer smatram da je Beogradski pakt ključan za našu politiku. Savez sa Slovenima nam dozvoljava da na mogućnost Anšlusa gledamo sa vedrinom. Posle potpisa Pakta, kralj mi je rekao da taj događaj smatra kao najvažniji uspeh režima. Zatim, zbog lične simpatije prema Stojadinoviću. Snažan, uzavrele krvi, sa gromkim smehom i čvrstim stiskom ruke, to je čovek koji uliva poverenje. Pun je samopouzdanja i ima pravo za to. Od političara koje sam dosad sreo na svojim evropskim putovanjima, on me najviše interesuje. Francuzi i Englezi gutaju gorke pilule zbog ove posete. Na osnovu jednog uhvaćenog telefonskog razgovora između engleskog atašea za štampu i jednog novinara, ispostavilo se da britanska ambasada širi vesti kako se spremamo da iskoristimo Stojadinovićevu slabost prema lepim ženama da bi ga što više privezali za naš vagon. Ovo je delimično tačno. Duče se nasmejao kada sam mu rekao da sam pored zvaničnih prijema, spremio i nekoliko balova sa najlepšim ženama rimskog društva“. ${ }^{9}$ Jasno je da italijanska strana nije ništa prepuštala slučaju i da je gost iz Jugoslavije zauzimao važno mesto, kako u sadašnjosti, tako i u planovima za budućnost. Poseta je zvanično objavljena 1. decembra, što je u italijanskoj štampi povezano sa tekstovima povodom proslave Dana ujedinjenja u Jugoslaviji.

\section{Stojadinovićev boravak u Italiji. Dve beleške}

Stojadinović je preko Postojne, Venecije i Bolonje pristigao u Rim sa suprugom Augustom kasno uveče 5. decembra. U pratnji mu je bio i jugoslovenski poslanik u Rimu Boško Hristić koji je predao akreditivna pisma kralju Viktoru Emanuelu III samo dvadesetak dana ranije. U delegaciji su bili i jugoslovenski novinari na čijem se čelu nalazio Milan Jovanović Stoimirović, direktor novinske agencije „Avala“. ${ }^{10}$ Istim vozom stigao je i poslanik u Beogradu Mario Indeli. Na stanici Termini dočekali su ga Musolini i Ćano sa brojnim zvaničnicima. Pored razgovora sa „,vođom fašizma“ i Ćanom tokom trodnevnog boravka u Rimu Stojadinovića je primio kralj ${ }^{11}$

${ }^{8}$ DDI, Ottava serie, Volume VII, br. 392, 481.

${ }^{9}$ Galeazzo Ciano, Diario 1937-1943 (Milano: BUR Rizzoli, 2010), 65-66. Stojadinović je bio oduševljen ovim zapisom pa ga je kasnije citirao u svojim memoarima.

${ }^{10}$ List Vreme navodi da se radilo o grupi od sedam novinara. Predsednik Centralnog presbiroa Kosta Luković došao je nešto kasnije.

${ }^{11}$ Stojadinović u svojim memoarima pominje i jednu zanimljivost. Na svečanoj večeri bila je i kraljica Jelena iz dinastije Petrović-Njegoš, ali je sa njom bio prinuđen da razgovara na francuskom jer je 
a nešto kasnije i papa Pije XI. U italijanskoj prestonici odseo je u vili „Madam“ za koju je nacrt radio čuveni slikar Rafelo. Jugoslovenski premijer je posetio vežbu fašističkih omladinskih organizacija sa Musolinijem u forumu koji je nosio ime domaćina, univerzitetski grad, vazduhoplovni centar „Gvidoniju“, nove gradove Litoriju, Pontiniju, Sabaudiju i Apriliju, ${ }^{12}$ kao i izložbu u Muzeju Starog Rima. U celokupnom programu angažovano je hiljade ljudi, a gost je obasipan pažnjom na svakom koraku.

Na putu do Milana pratili su ga Ćano i ministar propagande Alfijeri koji je ranije održao prijem za delegaciju srpskih novinara. Stojadinović je posetio fabriku automobila „Alfa Romeo“, fabriku gume „Pireli“, fabriku aviona „Kaproni“ i čuvenu milansku Skalu gde je sa suprugom prisustvovao izvođenju Pučinijeve opere „Boemi“. Tamo se sretao i razgovarao sa mnogima, od rukovodilaca do običnih radnika. Na severu Italije zadržao se nepuna dva dana. Teritoriju svog zapadnog suseda napustio je 10. decembra. I prilikom odlaska jugoslovenskom premijeru ukazano je poštovanje time što ga je Musolini ispratio na stanici u Rimu, a Ćano u Milanu.

Razgovori Musolinija i Stojadinovića predstavljaju centralni deo posete i vođeni su 6. i 7. decembra u palati ,Venecija“ u Rimu. Prema navodima štampe prvi je trajao oko pedeset minuta, a drugi sat i po. Radilo se o prvom ličnom susretu dva premijera. Tokom boravka u Italiji nisu potpisani novi ugovori već su dva predsednika vlade razmenila mišljenja o brojnim pitanjima vezanim za aktuelnu situaciju u Evropi i spoljnu politiku dve države. O toku i temama razgovora postoje dva zapisa koja su ostavili direktni učesnici. Radi se o zvaničnoj belešci italijanskog ministarstva spoljnih poslova i zapisu samog Stojadinovića u njegovim memoarima. Prva je zavedena nekoliko dana kasnije, 11. decembra, a navodi se da ju je redigovao lično Ćano koji je prisustvovao sastanku, dok je druga nastala nakon Drugog svetskog rata u Argentini kada je Stojadinović pisao svoje memoare (prvi put izdati posle njegove smrti 1963. godine). Dva zapisa se u generalnim crtama slažu po temama razgovora i diskusija, ali se neke izjave oba učesnika razlikuju; negde su u pitanju samo nijanse a negde bitne razlike. ${ }^{13}$

Delimičnu nesaglasnost nalazimo odmah na početku kada Stojadinović prenosi poruku kneza Pavla u kojoj kaže da se u budućnosti ,u bilo kojoj političkoj situaciji, Jugoslavija nikada neće naći u taboru protiv Italije“ (...la Jugoslavia non si troverà mai nel campo avverso all'Italia). ${ }^{14} \mathrm{U}$ zapisu jugoslovenskog premijera ta rečenica formulisana je mnogo blaže ,da će Jugoslavija voditi takvu politiku da ni u kom slučaju ne dođe u sukob sa svojim susedom s druge strane Jadranskog Mora“". ${ }^{15} \mathrm{U}$ italijanskoj verziji izjava je nedvosmislena, dok se Stojadinovićeva beleška može tumači-

gotovo zaboravila maternji jezik. Milan Stojadinović, Ni rat ni pakt (Rijeka: Otokar Keršovani, 1970), $444-445$.

${ }^{12}$ Radi se o četiri grada u provinciji Latina južno od Rima koji su podignuti tokom tridesetih godina na terenu dobijenom isušivanjem močvarnih predela.

${ }^{13}$ Neke aspekte ovog razgovora u najkraćim crtama pominje i američki istoričar Hoptner. J. Hoptner, $n . d ., 116-117$.

${ }^{14}$ DDI, Ottava serie, Volume VII, br. 690, 799. Pomenuti dokument objavljen je i u Jugoslaviji posle Drugog svetskog rata ali ćemo zbog određenih nepreciznosti prevoda tekst navoditi prema originalu. Tajni arhivi grofa Ciana (1936-1942) (Zagreb: Državno izdavačko poduzeće Hrvatske, 1952), 151-154.

${ }^{15}$ M. Stojadinović, $n$. d., 438. 
ti da će Jugoslavija dati sve od sebe da se ne nađe nasuprot Italije u budućim događajima. Kao što ćemo videti dalje ovo je samo jedan od nekoliko sličnih momenata. Glavne teme razgovora bile su odnosi dve države sa: Engleskom, Francuskom, Mađarskom, Austrijom, Čehoslovačkom, Balkanskim savezom i Društvom naroda. U belešci italijanskog Ministarstva spoljnih poslova kao prva tema ističe se Španija, koja kod Stojadinovića upadljivo nedostaje. Navodi se kako je upravo jugoslovenski ministar pokrenuo tu temu želeći da čuje šta duče ima da kaže o njoj. Razgovor se završio Stojadinovićevom podrškom italijanskoj politici u Španiji i njegovim simpatijama prema režimu generala Franka. ${ }^{16}$

Pitanje odnosa sa dve zapadne demokratije - Engleskom i Francuskom posebno je bilo interesantno. Budući da je nedavno bio u obe prestonice Stojadinović je imao potrebu da iznese svoje utiske. Požurio je da podvuče da „taj put nije doveo ni do kakvog praktičnog rezultata“. Vesti koje je preneo Musoliniju sigurno su mu godile, jer je s jedne strane istaknuta engleska nespremnost za rat i zaziranje od italijanske vojne moći a s druge velike suprotnosti u političkom životu Francuske koje „onemogućavaju svaku pozitivnu odluku“. Oba izveštaja se slažu oko opisa situacije. Kod Stojadinovića, međutim, nedostaje ono što je on rekao da namerava da učini povodom toga. U italijanskom dokumentu navodi se njegov plan da iskoristi slabost Francuske koja je otvoreno radila protiv njega u prošlosti i da ,proširi temelje svoje vladavine $\mathrm{i}$ to stvaranjem velike stranke, koja je već u toku, ta će stranka na prvom mestu imati cilj da organizuje snage jugoslovenske omladine. Sve će to dovesti do sve jačeg zbližavanja s političkim sistemom autoritarnih država i do udaljavanja od Francuske“.${ }^{17}$ Vezano za odnose sa Francuskom Stojadinović je takođe propustio da zapiše da je još jednom jasno obavestio Musolinija kako je odbio da potpiše sporazum o uzajamnoj pomoći između Francuske i Male antante koji je Pariz nudio i da će ga odbiti i prilikom narednog susreta u Beogradu sa ministrom spoljnih poslova Delbosom, koji je sledio nakon povratka iz Italije.

U narednom bloku koji je doticao odnose prema državama Srednje Evrope duče je istakao povezanost italijanske politike sa Mađarskom i odricanje bilo kakve pomoći Čehoslovačkoj. Stojadinović je, naime, na sastanku izneo molbu Beneša da se raspita kod Musolinija da li je moguć bilo kakav vid saradnje Čehoslovačke i Italije. Oko ove činjenice slažu se obe beleške. Zanimljivo je što je italijanski dokument zapisao i način na koji je jugoslovenski ministar izneo predlog, da on pritom ,ne dodaje ni jednu sopstvenu reč ni u pravcu preporuke, ni u pravcu pritiska““. ${ }^{18}$ Osim problema u Maloj antanti jasno su se ocrtali i problemi u Balkanskoj antanti. U memoarskom zapisu Stojadinović piše kako Turska i Grčka nisu srećne zbog zbliženja Jugoslavije i Italije. Upadljivo je izostavio svoje komentare o tome da su se odnosi, iako „formalno korektni“, pogoršali „naročito što se tiče iskrenosti“, kao i svoje obećanje

${ }^{16}$ Navodi se kako je Stojadinović rekao da se sprema da pošalje svog diplomatskog agenta u Frankovu tadašnju prestonicu Salamanku dok sa vladom u Madridu Jugoslavija ,nije imala stvarnih diplomatskih odnosa“. DDI, Ottava serie, Volume VII, br. 690, 799.

${ }^{17}$ Isto, 800 .

${ }^{18}$ Isto. 
da će ,u odnosu prema Turskoj i Grčkoj svoju politiku sve više usklađivati s politikom Rima“. ${ }^{19}$

Završni deo razgovora donosi još jednu krupniju nesaglasnost između dva svedočenja. Naime, Musolini je rešio da tokom decembra Italija zvanično istupi iz Društva naroda i ljubazno je ponudio da se sve to pomeri za nekoliko dana ukoliko bi Stojadinović smatrao da može imati nekih problema zbog bliskosti dana njegove posete sa formalnim činom italijanskog istupanja iz organizacije. Jugoslovenski premijer je smatrao da nema nikakve potrebe za odlaganjem, sa čime se slažu oba zapisa. Naravno, ponovo je razlika u tome na koji je način to izrečeno. U memoarima Stojadinović piše da je Društvo naroda izgubilo svoj smisao još od početka jer SAD nisu ušle u tu organizaciju, a ,posle izlaska Japana, Nemačke i sada Italije, ono još manje znači“ “. ${ }^{20} \mathrm{U}$ belešci italijanskog ministarstva jugoslovenski premijer ne samo što je „bezuslovno“ podržao odluku Musolinija već je i obećao da će lično napisati komentar u kome kaže da „sa izlaskom Italije iz Ženeve Društvo Naroda gubi svaku funkciju i vrednost" (con l'uscita dell'Italia da Ginevra la Societa delle Nazioni viene a perdere ogni funzione e valore). ${ }^{21} \mathrm{Na}$ samom kraju razgovora bilo je reči o ekonomskoj i vojnoj saradnji. Razgovaralo se o tome da u Italiju dođe nekoliko vojnih i tehničkih misija iz Jugoslavije da bi se upoznali sa stanjem u italijanskoj vojnoj industriji.

Možemo zaključiti da su obe strane bar delimično prilagodile izveštaje svojim pogledima i afinitetima. Ipak, u ovom slučaju beleška italijanskog ministarstva je verodostojnija. Stojadinović je, ili zbog želje da ostavi što bolji utisak na domaćine ili zbog toga što je stvarno verovao u to, svesno podilazio željama i nadanjima fašističkog vođe. Njegove priče o stvaranju autoritarnog režima sličnom onom u Italiji, o želji za što bližim odnosima na svim poljima, o tome kako će politiku sve više usklađivati sa italijanskom sigurno su služile toj svrsi. ${ }^{22}$ Kao majstor propagande, ali i pragmatičan čovek, znao je šta u kojoj prilici treba da kaže i uradi.

Ćano je bio veoma zadovoljan posetom. Zaključio je kako se Stojadinoviću svidela diktatura i da želi da taj sistem primeni i u svojoj zemlji. Kaže da je „usvojio rimski pozdrav i da nosi kaput sa antilop postavom jer izgleda više vojnički““ ${ }^{23}$ Procenjivao je da će Stojadinović sigurno ostati na vlasti još četiri godine do punoletstva kralja, a verovatno i nakon toga. Ćano zaključuje da je posetom postavljen temelj budućeg saveza koji bi „mogao da deluje u raznim pravcima. Jednog dana, možda i

${ }^{19}$ Isto, 801.

${ }^{20}$ M. Stojadinović, $n$. d., 440.

${ }^{21}$ DDI, Ottava serie, Volume VII, br. 690, 801. U navedenom prevodu na srpskohrvatski piše „gubi svu svoju važnost i pravo na opstanak“ što smatramo previše slobodnim prevodom koji ne odgovara u potpunosti izrečenom. Tajni arhivi, 154.

${ }^{22}$ Slično obrazloženje Stojadinović je dao britanskom poslaniku u Beogradu ser Ronaldu Kembelu (Cambell) koga je uveravao da je doček koji mu je priređen u Rimu ,godio njegovoj ličnoj sujeti, ali da mu nije zavrteo mozak“ i ,da se u Rimu nije dogodilo ništa što bi na bilo koji način moglo izazvati promenu politike jugoslovenske vlade“. Inače, sastanak Stojadinovića i Kembela iniciran je iz Londona, a povod je bila izjava jugoslovenskog premijera italijanskom listu Popolo d'Italia u kojoj je rečeno da „svet dobro zna da se više ne može računati na nesporazume između Jugoslavije i Italije“ za koju je britanska vlada tražila objašnjenje. Stojadinović je demantovao da se pomenuta izjava odnosila na Englesku već da su u pitanju bile Mađarska i Bugarska. Ž. Avramovski, Britanci o Kraljevini Jugoslaviji II, 561-562.

${ }^{23}$ G. Ciano, Diario, 66. Beleška od 8. decembra. 
prema severu““. ${ }^{24}$ Pod severom je, očigledno, mislio na Hitlerovu Nemačku. Sam Stojadinović ocenjuje da ,iako za vreme mog boravka u Rimu i Milanu nikakvi novi ugovori nisu bili zaključeni, ni potpisani, moji razgovori sa Musolinijem i Ćanom još više su učvrstili pravac politike, čije su osnove postavljene u ugovorima potpisanim marta meseca u Beogradu. Ta osnova značila je: mir na obalama Jadrana i osiguranje protiv eventualnog nemačkog nadiranja u pravcu Sredozemnog mora“،. ${ }^{25}$ Političko približavanje u 1937. godini otvorilo je vrata i kulturnoj saradnji u koju je italijanska vlada počela da ulaže značajne napore i sredstva. Prva vidljiva posledica toga bila je velika izložba „Italijanski portret kroz vekove“ održana od 28. marta do 9. maja naredne godine. ${ }^{26}$

\section{Recepcija u štampi}

U drugom delu rada bavićemo se recepcijom posete u italijanskoj i jugoslovenskoj štampi. Izbor je pao na po dva najtiražnija i najuticajnija lista u obe zemlje: Korijere dela sera (Corriere della Sera) i La stampa za fašističku Italiju ${ }^{27}$ i Politika i Vreme za Kraljevinu Jugoslaviju. ${ }^{28}$ Jugoslovensko Ministarstvo inostranih poslova konstatovalo je da je ,italijanska štampa sa puno topline komentarisala ovu posetu g. Stojadinovića Rimu“. Opšti zaključak nakon pregleda štampe bio je da „Italija ne traži u Jugoslaviji nikakvu suprematiju, da Italija poštuje nezavisnost svake države i zasniva svoje odnose na jednoj zdravoj i iskrenoj saradnji““. ${ }^{29}$ Koliko su stvarno bila tačna ova zapažanja videćemo na pisanju dva najtiražnija italijanska lista toga doba.

Štampa u Italiji, naročito nakon 1926. godine, bila je dirigovana i kontrolisana od strane režima. Na vrhu piramide kontrole nalazilo se Ministarstvo za štampu i propagandu (Ministero per la Stampa e la Propaganda) koje je tokom 1937. godine preimenovano u Ministarstvo narodne kulture (Ministero della Cultura Popolare, skraćeno MinCulPop). ${ }^{30}$ Ono je redakcijama davalo precizna uputstva kako izabrati

${ }^{24}$ Isto, 67. Beleška od 11. decembra.

${ }^{25}$ M. Stojadinović, n. d., 449.

${ }^{26}$ Više o italijanskoj kulturnoj politici prema Jugoslaviji i samoj izložbi videti u: Alberto Basciani, „The Ciano-Stojadinović agreement and the turning point in the Italian cultural policy in Yugoslavia (1937-1941)“, u: Italy's Balkan Strategies $\left(19^{\text {th }}-20^{\text {th }}\right.$ Century), urednik Vojislav G. Pavlović (Beograd: Institute for Balkan Studies of the Serbian Academy of Sciences and Arts, 2014), 199-212; Bojan Simić, „Izložba Italijanski portret kroz vekove u Beogradu 28. mart - 9. maj 1938“, Istorija 20. veka, XXXI, br. $1,(2013), 23-34$.

${ }^{27}$ Prema podacima za 1939. godinu Korijere dela sera je imala tiraž oko 600.000 primeraka a $L a$ stampa 300.000, približno koliko i drugi torinski list Gazeta del popolo. Đovani Gocini, Istorija novinarstva (Beograd: Clio, 2001), 324.

${ }^{28}$ Politika je tokom tridesetih godina imala tiraž oko 150.000 primeraka, dok je Vreme 1937. godine bilo na 130.000 da bi taj broj kasnije opao. Бојан Симић, Пропаганда Милана Стојадиновића (Београд: Институт за новију историју Србије, 2007), 121-144.

${ }_{29}$ Извештаји Министарства иностраних послова Краљевине Југославије за 1937. годину, књига VIII (Београд: Архив Југославије, 2013), 631.

${ }^{30}$ Više o delatnosti pomenutog ministarstva videti: Nicola Tranfaglia, La stampa del regime 1932-1942, Le veline del Minculpop per orientare l'informazione (Milano: Bompiani, 2005); Philip V. Cannistraro, La fabbrica del consenso: fascismo e mass media (Roma, Bari: Laterza, 1975); Giancarlo Ottaviani, Il controllo del Minculpop sulla pubblicità, il cinema, la moda, la cucina, la salute e la stampa (Milano: Todariana, 2007). 
vesti, sastavljati naslove, prelamati tekst, kakav jezik i stil treba koristiti. Uoči rata ovo ministarstvo izdavalo je oko 4.000 direktiva godišnje. ${ }^{31}$

Uz instrukcije da se o ovoj poseti piše u skladu sa željama režima ministarstvo propagande imalo je i jednu specijalnu direktivu. Naime, 7. decembra listovima je upućena instrukcija da se ,ne da utisak da Nemačka i Italija žele da nagrade ili se nadaju ulasku Jugoslavije u Antikominterna pakt “. ${ }^{32}$ Ovo je bilo u skladu sa stavovima samog Stojadinovića koji, mada izraziti antikomunista, nije želeo da se uključi u pomenuti pakt jer je u njemu video instrument spoljne politike fašističkih država. $^{33}$

Zajedno sa zvaničnom objavom skore posete Stojadinovića Italiji Korijere dela sera je na naslovnoj strani donela dva članka koja su veoma pohvalno govorila o jugoslovenskom premijeru. Radi se o čoveku koji je zaslužan za dobrobit svoje zemlje ali takođe, i to ,ne u maloj meri i za evropski mir“. U istom članku on je označen kao ,prijatelj Italije“ pod čijom vladom su pokrenuti javni radovi i Jugoslavija sada podseća Italijane na ,prve godine fašizma““. ${ }^{34}$ I La Stampa u članku sa identičnim naslovom najavljuje posetu Stojadinovića, daje njen okviran program i ukazuje na njegove zasluge za italijansko-jugoslovenski sporazum. U narednim danima listovi se osvrću na Stojadinovićevu politiku i podvlače njegove rezultate u spoljnoj politici, ekonomiji, kao i na smirivanju strasti u samoj zemlji. Teza o tome kako je Stojadinović pravi nastavljač Nikole Pašića i u narednim danima i nedeljama biće često ponavljan motiv u italijanskoj štampi. Za torinski list najavne tekstove je pisao njihov dopisnik iz Beograda Alfio Ruso. ${ }^{35}$ Njegova oba članka objavljena su na prvim stranama izdanja La stampe. I tokom posete Ruso je nastavio da objavljuje članke o uspesima Stojadinovićeve vlade i prenosio komentare o pisanju jugoslovenske štampe, koji su paralelno objavljivani sa informacijama o toku premijerovog boravka u Italiji. Slično je činio i list Korijere dela sera sa tekstovima svog dopisnika iz Beograda.

U danima posete oba vodeća italijanska lista su na naslovnim stranama do detalja pratili kretanje jugoslovenskog premijera, njegove izjave, aktivnosti i ponašanje. Naravno, isticali su i dobru organizaciju, glorifikovali rad Musolinija i napredak Italije pod njegovim režimom. Praćena je i delatnost gospođe Stojadinović, pa su tako registrovane njene posete školama i spomenicima u društvu gospođa Alfijeri i Hristić u Milanu. Od brojnih fotografija nastalih tokom posete posebno je zanimljiva ona koju je Korijere dela sera objavila na naslovnoj strani u izdanju od 11. decembra na kojoj se vidi Stojadinović u prvom planu kako pozdravlja rimskim pozdravom dok je iza njega Ćano. Fotografija je propraćena naslovom „Omaž Stojadinovića i Ćana pred spomenikom palim milanskim fašistima“. Dalji tekst nije ni bio neophodan. Ovim je najtiražniji dnevni list u Italiji prikazao Stojadinovića ne samo rečima, već i slikom, u najmanju ruku kao poštovaoca fašizma.

${ }^{31}$ Đ. Gocini, n. d., 322-323.

${ }^{32} \mathrm{~N}$. Tranfaglia, La stampa del regime, 248.

${ }^{33}$ M. Stojadinović, $n$. d., 514.

34 „Stojadinović a Roma in visita ufficiale“, Corriere della Sera, 2. 12. 1937, 1.

35 Alfio Russo (1902-1976), poznati italijanski novinar. Radio je za mnoge italijanske listove fašističke epohe, često kao dopisnik iz inostranstva. Vrhunac karijere doživeo je posle rata kada je nepunih sedam godina bio urednik lista Corriere dela Sera. 
Nakon šire analize pisanja torinske La stampe tokom 1937. godine možemo zaključiti da je upravo taj mesec bio presudan za formiranje pozitivnog mišljenja u italijanskoj štampi o Stojadinoviću. U toj godini objavljeno je ukupno 188 članaka, vesti i informacija u kojima se jugoslovenski premijer pominjao a od toga čak 74 (oko 40\%) objavljeno u decembru, uglavnom vezano za pripreme, samu posetu i njene posledice. Na isti zaključak ukazuje i analiza objavljenih fotografija. Tokom Stojadinovićevog boravka u Italiji La stampa je u svojim izdanjima objavila čak 15 različitih fotografija na kojima se nalazi jugoslovenski premijer (pre toga svega 4). Posebno je zanimljivo izdanje od 8. decembra čija naslovna strana donosi čak dve njegove fotografije: na prvoj sa Musolinijem dok se u pozadini nalazila gospođa Stojadinović, a na drugoj sa oficirima prilikom posete Vatikanu. Tako je jugoslovenski premijer postao jedna od retkih ličnosti koja je imala više fotografija na jednoj strani od fašističkog vođe. ${ }^{36}$ To je samo jedna od ilustracija izuzetne pažnje koja mu je ukazana.

Jugoslovenski najtiražniji listovi Politika i Vreme imali su drugačija polazišta. Politika, stari i ugledan list koji je osnovala porodica Ribnikar 1904. godine, pokušavao je tokom vremena da odbije pritiske različitih vladajućih krugova i održi svoju neutralnost. Za vreme vlade Milana Stojadinovića zadržan je pomenuti kurs, list nije bio pod većim pritiskom vlasti ali je morao da otpusti neke komunistički nastrojene novinare. ${ }^{37}$ S druge strane Vreme, osnovano 1921. godine, od februara 1936. faktički je pripadalo Stojadinoviću i njegovoj porodici, pa ne čudi što je taj list daleko prisnije podržavao njega i politiku koju je vodio. I sam premijer je imao uticaja na njegovo uređivanje. ${ }^{38}$

Politika je u članku koji najavljuje posetu istakla da ,ne treba očekivati nikakvih senzacija“ već da se radi o uzvratnoj poseti grofu Ćanu i da je to akt „međunarodne kurtoazije kao i znak da su se odnosi između Jugoslavije i Italije za poslednjih šest meseci razvijali u duhu prijateljstva“. ${ }^{39}$ Uglavnom je prenošeno pisanje italijanskih listova koji su u pozitivnim tonovima govorili o Stojadinoviću i njegovom dolasku u Italiju. Vreme je najavi posete posvetilo mnogo više prostora. Prenoseći pisanje Đornale d'Italija u kome se hvalio sporazum dve države podvučeno je kako on „odgovara idejama Pašića čiji je dr. Stojadinović genijalan, odlučan i hrabar sledbenik“ i da će on naići na „srdačnost, divljenje i poštovanje koje zbog svoje jasne i konstruktivne politike i zaslužuje“ ". ${ }^{40}$ Slično ideji pomenutog članka Vreme piše specijalnu najavu posete pod naslovom „Put u Rim tragom Pašića“ koji je objavljen 5. decembra. U njemu se povlači potpuna paralela između Pašićevog boravka u italijan-

${ }^{36}$ U izdanju La Stampa od 6. decembra oba predsednika vlade imaju po dve fotografije od kojih je jedna zajednička, sa rimske železničke stanice Termini. Više o prikazivanju Stojadinovića u listu $L a$ stampa videti u: Бојан Симић, „Торински дневник Ла Стампа о Милану Стојадиновићу“, Токови uсторије, бр. 2, (2015), 41-55.

${ }^{37}$ Миодраг Симић, Лист „Политика“ и његов утицај на ширење демократских идеја у периоду између два рата (Београд: Правни факултет у Београду, 1987), 153-154.

${ }^{38}$ O Stojadinovićevom odnosu prema listu Vreme videti svedočenje jednog njegovog bliskog saradnika: Милан Јовановић Стоимировић, Дневник 1936-1941 (Нови Сад: Матица српска, 2000), 404-408.

${ }^{39}$ Милан Радуловић, „Претседник владе г. др. Стојадиновић отпутовао је синоћ за Рим да врати посету грофу һану“, Политика, 5. 12. 1937, 1.

40 „Pisanje štampe“, Vreme, 3. 12. 1937, 1-2. Kao autor članka navodi se italijanski novinar Virđinije Gajda. 
skoj prestonici 1924. godine i tada postignutog sporazuma, a Stojadinović označava kao vredni nastavljač te politike. Kao specijalnog izveštača u Rim Vreme je poslalo poznatog novinara Miodraga Mihailovića Svetovskog, čoveka od poverenja predsednika vlade. ${ }^{41}$ Za razliku od izveštača Politike Radulovića on piše mnogo dopadljivije i stilski lepše, ali ono što ga posebno ističe jeste njegovo veličanje Musolinija. Za njega je duče ,,socijalista u službi nacije“, ,,veliki neimar“ koji od Italije zida ,fantastičnu zgradu“ za „decenije i vekove“" 42 Takve formulacije se kod Radulovića neće naći. On nudi obilje informacija, prepričava događaje do najsitnijih detalja, ističe veoma dobru organizaciju i pripremu, ali nema preterivanja i glorifikacije. Inače, oba novinara su pratila tok posete, a izveštaje redakcijama davali telefonom.

Sadržaj razgovora Musolinija i Stojadinovića ostao je van domašaja domaćih novinara jer sastanke nije pratilo zvanično saopštenje i osim nekih formalnih elemenata oni o njima nisu pisali. Svetovski je samo konstatovao da se radi o ličnostima „koje su odlučile snažnim voljama novi tok istorije u ovom kutu Evrope“. Zdravice koje su dva premijera dali na svečanoj večeri bile su prenesene u celosti, a o posetama i obilascima govoreno je detaljno.

U izveštavanju Politike i Vremena tokom Stojadinovićeve posete u Italiji primećujemo neke konstante i neke razlike. Boravku u Italiji predsednika vlade očekivano je dato centralno mesto u štampi tih dana. $O$ tome se pisalo opširno $\mathrm{i}$ isključivo u pozitivnom tonu. Detaljno je prenošeno pisanje strane štampe iz više različitih zemalja, ali su gotovo svi izabrani tekstovi i delovi tekstova bili pozitivni ili umereni. Ono što izdvaja pisanje lista Vreme od Politike jeste glorifikacija rezultata fašizma u Italiji. Svetovski je odavao utisak nekog ko je oduševljen onim što je video pa i ne čudi ovakav zapis: „Rođena je za ovih 15 godina jedna nova Italija koju je grehota nepoznavati. To je Italija kojoj je rad nacionalna dužnost, nacija ideal, a stvaranje dostojno divljenja“".

Panegirični ton o Italiji i dostignućima fašizma kod Svetovskog je kulminirao u poslednjem izveštaju kada je sumirao utiske o poseti. U fašizmu je prepoznao ,humaniji i prijateljskiji odnos rada i kapitala“, dok o svom najjačem utisku kaže: ,preobraženje fabrika i nacionaliziranje radničkog elementa za nas ostalo najveće čudo fašističke Italije, koje smo svojim očima videli““. ${ }^{44} \mathrm{Za}$ razliku od njega Radulović je prilično umereno $\mathrm{i}$ informativno prenosio ono što je video imajući potpuno u fokusu jugoslovenskog premijera i delegaciju i njihovu višednevnu delatnost na Apeninima. Imajući u vidu bliskost Stojadinovića sa listom Vreme jasno je koji je način izveštavanja njemu više godio i na koji je imao više uticaja.

${ }^{41}$ Miodrag Mihailović Svetovski (Krupanj, 1898 - Beograd, 1941). Učestvovao u povlačenju preko Albanije da bi kasnije studirao filozofiju na Sorboni. Između dva rata bavio se novinarstvom i sarađivao sa brojnim beogradskim listovima: Samouprava, Vreme, Naša krila i drugim. Smrt ga je zatekla na mestu urednika Obnove. Stoimirović u svom dnevniku tvrdi da je Stojadinović redovno primao Svetovskog i konsultovao se sa njim o važnim pitanjima u koja su čak spadala i postavljenja poslanika i dopisnika. М. Јовановић Стоимировић, н. д., 183.

${ }_{2}$ М. Световски, „Припреме Рима за дочек г. др. Стојадиновића“, Време, 6. 12. 1937, 3.

${ }^{43}$ М. Световски, „Испраћен од Дучеа г. др. Стојадиновић отпутовао је синоћ са грофом Ћаном за Милано“, Време, 10. 12. 1937, 3.

${ }^{44}$ М. Световски, „У тисци из Италије“, Време, 11. 12. 1937, 3. 
Jugoslovenski listovi su slično italijanskim prenosili pisanje strane štampe o poseti. Navođeni su članci iz desetak evropskih zemalja, koji su svi govorili pozitivno o Stojadinovićevom boravku u Italiji i značaju sporazuma dve zemlje za evropski mir. Tako Politika prenosi mađarski Pester Lojd čiji zaključak kao da je izašao iz kuhinje domaćih propagandista: „Politika jugoslovenskog predsednika vlade pojačava tezu da je moguće na jednoj strani održati stare veze, a uz to miroljubivom politikom dovesti i do prijateljske saradnje između država čiji je zajednički interes da dejstvuju na privrednom i kulturnom razvitku svojih naroda i na održavanju mira na evropskom kontinentu. Kada jednom sve države Evrope pođu putem koji im Italija i Jugoslavija tako mudro pokazuju, onda će biti mnogo bliži i mir koji danas izgleda tako daleko". ${ }^{45}$ Slični hvalospevi pronađeni su u bugarskoj, rumunskoj, pa i čehoslovačkoj štampi. Naravno, najčešće su prenošeni citati iz italijanske štampe, kao što su fašistički listovi prenosili jugoslovenske.

Na kraju i jedna zanimljivost. Na početku i tokom boravka u Italiji Stojadinović je potpuno usvojio „rimski pozdrav“ što se može videti na tada snimljenim teleđornalima ${ }^{46}$ i na fotografijama koje su objavljivali italijanski listovi. Tih fotografija, međutim, nije bilo u vodećim jugoslovenskim listovima. Na nekima se čak vidi Stojadinović kako stoji mirno dok ljudi oko njega pozdravljaju karakterističnim pozdravom. Jasno je da ovo nije nikakav plod slučajnosti već direktiva da se takve fotografije ne objavljuju zbog domaće javnosti koja je na fašizam još uvek gledala kao na „javno zlo“, kako je zapisao dopisnik agencije „Stefani“ Korado Sofija krajem 1936. posle svog jednogodišnjeg boravka u Beogradu. ${ }^{47}$

\section{Zaključna razmatranja}

Poseta Italiji koju je predsednik jugoslovenske vlade i ministar spoljnih poslova Milan Stojadinović obavio u prvoj polovini decembra 1937. izuzetno je značajna za razumevanje spoljne politike obeju država, kao i načina razmišljanja njihovih neposrednih sprovodilaca. Na osnovu svedočenja ministra Ćana i ponašanja samog jugoslovenskog premijera jasno je da je Stojadinoviću godila sva pažnja koju je dobijao, kao i da je gajio određene simpatije prema fašističkom uređenju države. Imajući u vidu da se radi o čoveku koji je jako obraćao pažnju na propagandu, Stojadinović se trudio da ostavi baš onakav utisak kakav je znao da domaćin očekuje od njega. Nakon posete spoljna politika obe zemlje nastavila je da se razvija u zadatom pravcu. Italija je napustila Društvo naroda a u narednim periodu pokušala da uključi Jugoslaviju u svoje planove, naročito što se tiče podele Albanije. Stojadinović je nastavio da razvija novi pravac svoje politike koji je ovom posetom samo dodatno utvrđen.

45 „Пестер Лојд“ о политици Југославије и Италије“, Политика, 9. 12. 1937, 2.

${ }^{46} \mathrm{Na}$ sajtu arhiva Luce (http://www.archivioluce.com/archivio/\#n) mogu se videti dva kratka filma i to: Saggio ginnico-militare della Gioventù Italiana del Littorio davanti al Duce e al Primo ministro iugoslavo Stojadinovich presso il Foro Mussolini snimljen tokom posete Rimu i La visita del primo ministro iugoslavo Stoiadinovich a Milano iz Milana.

47 Бојан Симић, „Један извештај о Краљевини Југославији и италијанској пропагандној акцији 1936. године“, Токови историје, бр. 2, (2011), 189. 


\section{IZVORI I LITERATURA}

- Archivio Storico Luce, Archivio Cinematografico

- Avramovski, Živko. Britanci o Kraljevini Jugoslaviji II. Zagreb: Globus, 1986.

- I Documenti Diplomatici Italiani (DDI), Ottava serie: 1935-1939, Volume VII. Roma: Istituto Poligrafico e Zecca dello Stato, 1997.

- Извештаји Министарства иностраних послова Краљевине Југославије за 1937. годину, књига VIII. Београд: Архив Југославије, 2013.

- Tajni arhivi grofa Ćana (1936-1942). Zagreb: Državno izdavačko poduzeće Hrvatske, 1952.

- Јовановић Стоимировић, Милан. Дневник 1936-1941. Нови Сад: Матица српска, 2000.

- Ciano, Galeazzo. Diario 1937-1943. Milano: BUR Rizzoli, 2010.

- Stojadinović, Milan. Ni rat ni pakt. Rijeka: Otokar Keršovani, 1970.

- Corriere della Sera (1937)

- La Stampa (1937)

- Време (1937)

- Политика (1937)

- Avramovski, Živko. Balkanske zemlje i velike sile 1935-1937. Beograd: Prosveta, 1968.

- Basciani, Alberto. „The Ciano-Stojadinović agreement and the turning point in the Italian cultural policy in Yugoslavia (1937-1941)“. U: Italy's Balkan Strategies (19th - 20th Century). Urednik Vojislav G. Pavlović, 199-212. Beograd: Institute for Balkan Studies of the Serbian Academy of Sciences and Arts, 2014.

- Biber, Dušan. „O padu Stojadinoviće vlade“. Istorija 20. veka, Zbornik radova, VIII, (1966), 5-71.

- Bucarelli, Massimo. Mussolini e la Jugoslavia 1922-1939. Bari: Edizioni B. A. Graphis, 2006.

- Cannistraro, Philip V. La fabbrica del consenso: fascismo e mass media. Roma, Bari: Laterza, 1975.

- Gocini, Đovani. Istorija novinarstva. Beograd: Clio, 2001.

- Ђурковић, Миша. „Спољна политика Милана Стојадиновића“. У: Милан Стојадиновић: Политика у време глобалних ломова, Зборник радова. Приредио Миша Ђурковић, 44-74. Београд: Завод за уџбенике, 2013.

- Hoptner, Jacob B. Jugoslavija u krizi 1934-1941. Rijeka: Otokar Keršovani, 1972.

- Krizman, Bogdan. Vanjska politika jugoslavenske države 1918-1941. Zagreb: Školska knjiga, 1975.

- Ottaviani, Giancarlo. Il controllo del Minculpop sulla pubblicità, il cinema, la moda, la cucina, la salute e la stampa. Milano: Todariana, 2007.

- Simić, Bojan. „Izložba Italijanski portret kroz vekove u Beogradu 28. mart - 9. maj 1938“. Istorija 20. veka, XXXI, br. 1, (2013), 23-34. 
- Симић, Бојан. „Један извештај о Краљевини Југославији и италијанској пропагандној акцији 1936. године“. Токови историје, бр. 2, (2011), 187-193.

- Симић, Бојан. Пропаганда Милана Стојадиновића. Београд: Институт за новију историју Србије, 2007.

- Симић, Бојан. „Торински дневник Ла Стампа о Милану Стојадиновићу“. Токови историје, бр. 2, (2015), 41-55.

- Симић, Миодраг. Лист „Политика“ и његов утицај на ширење демократских идеја у периоду између два рата. Београд: Правни факултет у Београду, 1987.

- Stojkov, Todor. Vlada Milana Stojadinovića. Beograd: Institut za savremenu istoriju, 1983.

- Tranfaglia, Nicola. La stampa del regime 1932-1942, Le veline del Minculpop per orientare l'informazione. Milano: Bompiani, 2005.

Bojan Simić

\section{MILAN STOJADINOVIĆ'S VISIT TO ITALY IN DECEMBER 1937}

\section{Summary}

The official visit of Yugoslav Prime Minister and Minister of Foreign Affairs, Milan Stojadinović to Italy at the beginning of December 1937 is considered to be a courtesy call following Italian Foreign Minister Ciano's visit to Belgrade in March 1937 when Italian-Yugoslav Agreement was signed. During his stay in Rome, Stojadinović met Mussolini and talked about the current situation in Europe and foreign policies of two countries. He was also received by Italian King Victor Emanuel III and pope Pius XI. The second part of the visit took place in Milano were Yugoslav Prime Minister visited industrial complex and military center. Although no new agreements were signed, this visit is vitally important for understanding the politics of the two governments in the following months and years.

The press of both countries paid much attention to this visit and informed their public regularly and in detail about it. Leading Italian newspapers Corriere della Se$r a$ and La Stampa and Yugoslav Politika and Vreme were in the forefront. Hundreds of articles were written, dozen new photos were made and published on front pages. Italian and Yugoslav newspapers often republished foreign articles about the visit but exclusively theose with positive connotation, considering the visit as a crucial act for European peace at the time.

KEYWORDS: Italy, Yugoslavia, Milan Stojadinović, foreign policy, diplomacy, press, propaganda 


\section{LA VISITA DI MILAN STOJADINOVIĆ IN ITALIA NEL DICEMBRE 1937}

\section{Sommario}

La visita ufficiale di Milan Stojadinović, Primo Ministro jugoslavo e Ministro degli Affari Esteri, in Italia all'inizio di dicembre 1937. aveva l'obiettivo di ricambiare quella del conte Ciano che era stato a Belgrado nel marzo 1937. quando il Patto italiano - jugoslavo era stato firmato. Durante il suo soggiorno a Roma, Stojadinović incontrò Mussolini con cui parlò della situazione in Europa e delle politiche estere dei due paesi. Fu anche ricevuto dal re Vittorio Emanuele III e da Papa Pio XI. La seconda parte della visita si svolse a Milano dove il primo ministro jugoslavo visitò il complesso industriale e il centro militare. Nonostante nessun nuovo accordo sia stato firmato, questa visita è di importanza vitale per la comprensione della politica che $\mathrm{i}$ due governi avrebbero attuato nei mesi e anni sucessivi.

La stampa dei due paesi prestò molta attenzione a questa visita e informò regolarmente e dettagliatamente la loro opinione pubblica su essa. I principali quotidiani italiani Corriere della Sera e La Stampa e quelli jugoslavi Politika e Vreme erano in prima fila. Centinaia di articoli furono scritti, dozzine di nuove foto furono fatte e pubblicate sulle prime pagine. I giornali italiani e jugoslavi, spesso ristamparano articoli stranieri in merito alla visita, ma scegliendo esclusivamente quelli positivi che la consideravano un atto fondamentale per la pace europea.

PAROLE CHIAVE: Italia, Jugoslavia, Milan Stojadinović, Affari Esteri, diplomazia, stampa, propaganda 